\title{
Analysis of United States Propaganda Against North Korea Through The Film The Interview
}

Jessi Monika

Department of Political Science, Faculty of Social and Political Sciences, Universitas Sumatera Utara, Indonesia

\begin{tabular}{|c|c|}
\hline Article Info & ABSTRACT \\
\hline Article history: & \multirow{9}{*}{$\begin{array}{l}\text { This research tried to describe the propaganda made by United } \\
\text { States against North Korea through a movie entitled The } \\
\text { Interview. The movie Interview. The movue despict how the } \\
\text { communist state of North Korea is very closed and anti to foreign } \\
\text { countries eventually want to do an interview with the president of } \\
\text { North Korea. In the film The Interview United States producing } \\
\text { films on large-General for the state of North Korea, where the } \\
\text { United States and North Korea opposites in many ways, both in } \\
\text { terms of economics, ideology, and the perception of the public, } \\
\text { even in the use of nuclear weapons. The theory used in this } \\
\text { research is to analyze the theory of discourse analysis Norman } \\
\text { Fairclough, to understand the views of experts on the analysis of } \\
\text { discourse, the concept of propaganda techniques according to the } \\
\text { experts to understand the propaganda. By using interviews with } \\
\text { respondents drawn by profession, this study uses analysis of the } \\
\text { interview, the general condition of the two countries, critical } \\
\text { discourse analysis, and examined the scene and its relevance to } \\
\text { theories and concepts used. The overall results were obtained that } \\
\text { the film is a propaganda film The Interview United States against } \\
\text { North Korea, one of the film's release purpose is to divert North } \\
\text { Korea at the same time prevent North Korea did not attack the } \\
\text { United States with nuclear weapons. }\end{array}$} \\
\hline Received: Jan 9, 2020 & \\
\hline Revised: Sep 20, 2020 & \\
\hline Accepted: Apr 11, 2021 & \\
\hline Keywords: & \\
\hline $\begin{array}{l}\text { Propaganda; } \\
\text { Discourse Analysis: }\end{array}$ & \\
\hline Discourse Analysis; & \\
\hline North Korea; & \\
\hline United States of America. & \\
\hline
\end{tabular}

This is an open access article under the CC BY-NC license.

\section{Corresponding Author:}

Jessi Monika,

Department of Political Science, Faculty of Social and Political Sciences,

Universitas Sumatera Utara,

Street Dr. T. Mansur No. 9, Padang Bulan Campus, Medan, 20155, North Sumatra, Indonesia

Email: jessimonika@gmail.com

\section{INTRODUCTION}

Moving pictures (films) are the dominant form of visual mass communication in this part of the world(Kellner, 2011)(Watt, 2012). More than hundreds of millions of people watch movies in theaters, television films and laser video films each week. In the United States and Canada more than one million movie tickets are sold each year. American films produced in Hollywood(Risdiansyah, 2011)(Rifwan et al., 2015)(Oktora, 2015). The films made here flood the global market and influence the attitudes, 
behavior and expectations of people in other parts of the world. Film became a medium of entertainment earlier than broadcast radio and television. Watching films in theaters became a popular activity for Americans during the 1920 and $1950 s$. The film industry is a business industry(Sabatier et al., 2012). This predicate has shifted the opinion that people still believe that film is a work of art, which is produced creatively and fulfills the imagination of people with the aim of obtaining a perfect aesthetic (beauty)(Sartika, 2014)(Syafrul, 2014)(Csikszentmihalyi, 2015). Although in reality it is a form of art, the film industry is a profitable business, sometimes a money machine which is often for the sake of money, breaking out of the artistic norms of film itself (Sartika, 2014). Film is a mass communication medium which is very important to communicate the reality that occurs in everyday life, films have a strong reality, one of which tells about the reality of society (Baran et al., 2012)(Turow, 2011)(Sanborn \& Harris, 2013). Films can also be a place for public opinion or something to be conveyed to the public through films(Inkeles, 2013). Many things can be conveyed through films, be it about family, social problems that exist in the world such as violence, war or love for a country or nationalism, films are also usually in the form of a biography or life story of a leader who is known to the world (Wardani, 2011). Besides films are also often used as a medium for propaganda. As a propaganda medium, films have great reach, realism, emotional influence and popularity because films have the ability to reach large numbers of people in a fast time and the ability to manipulate the reality that appears in a photographic message without losing credibility. Even the propaganda efforts made, including through films, are regulated and coordinated by government agencies or institutions supported by the government.

The film The Interview is a film that tells the story of two men who work as host (Dave Skylark) and producer (Aaron Rapaport) loyal. This film tells about the luck of this host and producer because their show, Skylark Tonight, was favored by the president of North Korea, Kim Jong Un. Finally, Kim Jong Un invited Dave Skylark and Aaron Rapaport to North Korea for an exclusive interview. This is something that is very rare and shakes the world, considering that North Korea is willing to conduct interviews with the outside world, especially when interviews are conducted on US television. However, what the general public does not know is that the condition for conducting an interview is that all questions to be asked of Kim Jong Un must be from North Korea. If not, the interview will be terminated unilaterally.

This film depicts how the communist country, namely North Korea, which is very closed and anti to the outside world, finally wants to conduct an interview with the United States (Jati, n.d). North Korea is the only country in the world to be a communist with the Juche ideology, North Korea's first leader being Kim Il Sung. North Korean people often refer to him as the eternal president of North Korea. Kim Il Sung built the North Korean state with the help of the Soviet Union. Although in the end the relations between the two countries were not good. Kim Il Sung first formed the North Korean Labor party. This party will later become the ruling party in North Korea. Kim Il Sung is very well known for his Juche (independence) ideology, this ideology was the creation of Kim Il Sung. This is North Korean style Communism. In Kim Il Sung's book, Revolution and Socialist Construction in Korea, the Juche ideology contains "People who have lost their autonomy and independence can fall into revolutionism, dogmatism,(Ferawati, 2012).

Kim Il Sung believes that every human being determines his own destiny(Ferawati, 2012)(Lutz, 2015)(Yongchun, 2015). This ideology led Kim Il Sung to become the authoritarian leader of North Korea. The author sees this as Kim Il Sung's attempt to maintain his power. This Juche ideology is considered a legacy from Kim Il Sung. North Korean people think that Kim Il Sung is their savior. However, when it is seen clearly, this ideology is actually more of a hierarchical power, where the ruler chooses the next ruler himself through bloodline or descent. The North Korean people have indeed become an independent society with this ideology. However, North Korean society is a society that does not know the outside world and the development of the outside world, in this case the concrete example of communism with the Juche ideology is that humans become a source of great power, so that Kim Il Sung and his heirs are exalted as God. 
Kim Il Sung died July 8, 1994. He was succeeded by his son Kim Jong Il. Kim Jong Il had been prepared by Kim Il Sung to be his heir for 14 years(Park, 2014). He often joins Kim Il Sung in state visits or important meetings that the country participates in. Just when his father died Kim Jong Il issued his first order of 10 days of condolences for the death of their immortal leader. People are asked to cry and any kind of entertainment in the country is prohibited during times of mourning. The most surprising thing is that every citizen at home, school, office is obliged to display a photo of Kim Il Sung and himself, this is so that people always remember their leader. Kim Jong Il earned the nickname The Dear Leader and Half God (Nadjib, E. A, 2015).

Kim Jong Il began to make major changes to the system of government. This change since the collapse of the Soviet Union lost allies means losing a protective state, to cover it Kim Jong Il built a military with nuclear and missile technology. It builds up North Korea's armed forces at the expense of the welfare of its people. The international world, anxious about its policies, is trying to seduce to stop its nuclear program, North Korea's military strengthening program has succeeded in bringing the country to become the $5^{\text {th }}$ ranked country in terms of military power in the world.

Kim Jong Il's military program did pay off. Apart from the major powers being afraid of North Korea, no country has dared to take rash steps in attacking or cornering North Korea. The state money was used up to meet the needs of the military force, more and more people were starving and more people died from starvation. It's sad indeed, but the defense carried out by Kim Jong Il deserves thumbs up considering his efforts to defend his country with all his efforts. National defense and national survival are the most important things that should be the priority of a leader and that is what Kim Jong Il did while building up his military.

Kim Jong Il's leadership was given to his youngest son Kim Jong Un. Kim Jong Il died on December 17, 2011 and was announced to the North Korean public on December 19, 2011. Kim Jong Un replaced his father Kim Jong Il, in fact the whip of power fell to Kim Jong Nam. The incident of Kim Jong Nam going to Japan with a fake identity only to go to Disneyland made Kim Jong Il change his heir. Only 3 years Kim Jong Il taught Kim Jong Un about governance. Therefore, many people feel that Kim Jong Un is not yet worthy of being a leader. He is too young and still unstable. Kim Jong Un was assisted by his uncle in managing the North Korean state.

Kim Jong Un has recently risen to the surface with his crazy policies. Starting from executing his uncle to death, poisoning his aunt, people who are obliged to follow Kim Jong Un's haircut, there are rules that must pass Kim Jong Un's lessons, the execution of airport architects because they are not satisfied with the design. As if creating a sensation, Kim Jong Un aims to attract the world's attention with the things he does. The author sees that this North Korean president just wants to tell the world that he cannot be underestimated.

Thus propaganda is a potential weapon if it is used without thinking or considering the truth of the message conveyed by the communicator. Propaganda can be carried out in various ways, film is one of them. The word propaganda comes from the modern Latin "Propagere" which means developing or expanding then the meaning of propaganda is interpreted contextually as a series of messages that aim to influence the opinion and behavior of a community or a group of people. What is interesting for the author to see in this research is that usually films with the theme of a leader are usually produced by the country where the leader is the leader.

This is because the president provides benefits to many people and also has interests in the country. However, in the film The Interview, the United States produces a film that tells the story of Kim Jong Un, who has an important meaning for the North Korean state, where we know that the United States and North Korea are in many ways contradictory, both in terms of economy, ideology, perspective on society. , and even in the case of using nuclear-powered weapons.

The United States boldly criticized and made a picture of Kim Jong Un in the lens of the camera. The courage of the American film man made the depiction of a North Korean president who is known to be authoritarian, making this film controversial. A film can change a person or society's perspective on what he has never seen can be changed only with a camera lens and a few statements. The film The Interview became a phenomenal and controversial film in 2014 where the big company Sony Pictures 
was hacked and made by a country that has had a bad relationship with North Korea for a long time, seeing this means this film has a big impact on the hacker. Kim Jong Un's portrayal in this film had a great meaning for the people who watched him and a great impact. Where the picture of Kim Jong Un's true nature has been imprinted in the memory of the brain of the person watching. The author wants to see what propaganda is implied in this film in relation to the United States as a film-producing country.

\section{RESEARCH METHOD}

The method used in this research is a descriptive qualitative research method with a critical analysis approach in the perspective of propaganda in an American country whose ideology is liberalism. (Fahmi, nd)(Shi-Xu, 2012). The research method is defined as a research procedure that produces descriptive data in the form of written or spoken words from people and observable behavior.(Jervis \& Drake, 2014)(Khan, 2014). Qualitative methods refer to research procedures that produce descriptive data, what people write and say or observed behavior (Indarto, 2012)(Yilmaz, 2013)(Chowdhury, 2015). In other words, qualitative methods pave the way for how we perceive social reality. Considering that the object of research here is a cinematographic aspect, namely verbal and non-verbal signs consisting of various kinds of signs incorporated in a system, the method of critical analysis is in the perspective of propaganda in the United States, whose ideology Liberalism is here to see the message of the film and propaganda that is in the film. Furthermore, this research is also a descriptive study because the data and research results are presented in descriptive form.

In this research, the object of research in the film The Interview by director Seth Rogan is the whole of the scenes in the film.(Radner \& Stringer, 2012). The film is 112 minutes long. The main focus in this film is the snematographic aspect that is presented, namely: (a). Non-Verbal (Visual Image), namely the images contained in a compositional frame, what is the content or content of a shot. This image presents the content or content to be conveyed, in the form of a combination of different design elements and is a moving image. Movement produces meaning. (b). Verbal (Sound Source), Namely a sound source that will help understand the meaning. Sound will have an effect that complements the analysis of this film. This audio element is divided into musical dialogue and background.

The data analysis technique used in this research is to use qualitative descriptive data analysis techniques, namely by analyzing the existing problems so that then a clear picture will be obtained of the object to be studied and then conclusions will be drawn on the phenomenon being observed by the method. scientific (Prabowo \& Heriyanto, 2013)(Welch et al., 2011). The main principle that needs to be emphasized in this research is to find appropriate theories and facts(Slavich \& Zimbardo, 2012)(Siyoto \& Sodik, 2015). The steps taken in data analysis are as follows:

a) Researchers will try to review the general condition of the two countries (North Korea and the United States) as countries whose leaders are the main actors in the film The Interview and the country of the filmmaker. The general conditions that the researcher will discuss here are cultural, economic, political, social. The aim is that this research can be analyzed from many aspects.

b) Researching scenes or story ideas in the film The Interview. Then the researcher provides a point of view in seeing this film and also to make it easier for researchers to analyze the propaganda in this film.

c) In examining the scene the researcher used Norman Fairclough's Critical Discourse Analysis. As we know that discourse analysis developed by Sara Mills consists of two stages of analysis, namely: the relationship between the subject, the object and the position of the audience.

d) Describing propaganda theory and using propaganda techniques used by liberal countries in conducting propaganda. This theory will assist researchers in analyzing the propaganda implied in the film The Interview. 


\section{RESULTS AND DISCUSSIONS}

\subsection{Analysis of The Interview Film Propaganda Technique}

In this technique, the writer divides 7 scenes in the film The Interview which according to the writer are the key scenes in examining the propaganda implied in this film. Each scene lasts 15 minutes. Then each scene will be associated with the theory of propaganda by George (he has 12 types of propaganda techniques). In the film, the audience is invited to see two functions at once, namely verbal and nonverbal. Verbal is anything that is in the form of words uttered by film players (dialogue) or words spoken by someone without the presence of a figure who says it (prologue) and also a monologue. Verbal is used to clarify the existing situation and emphasize the needs of the player in this film. The verbal power in this film can increase the audience's emotions and also can easily change public opinion. Whereas in non-verbal, everything related to expression, lighthing, music, and so on. Non-verbal is anything that has nothing to do with manipulation between players. In non-verbal players are asked to show their expressions and emotions so that they attract attention and bring the audience as if they were in that state. In supporting this, the director needs lighthing, music and so on to emphasize the situation. From the explanation above, the writer also began to divide the 14 core scenes that I have chosen proportionally as scenes that show the existence of propaganda in the film The Interview: In non-verbal players are asked to show their expressions and emotions so that they attract attention and bring the audience as if they were in that state. In supporting this, the director needs lighthing, music and so on to emphasize the situation. From the explanation above, the writer also began to divide the 14 core scenes that I have chosen proportionally as scenes that show the existence of propaganda in the film The Interview: In non-verbal players are asked to show their expressions and emotions so that they attract attention and bring the audience as if they were in that state. In supporting this, the director needs lighthing, music and so on to emphasize the situation. From the explanation above, the writer also began to divide the 14 core scenes that I have chosen proportionally as scenes that show the existence of propaganda in the film The Interview:

a. Seconds to oo:34, minutes 01:35: a girl sings about "how great their president, Kim Jong Un, is our leader is very wise. He is gentle, kind and strong. We wish him happy, we wish him happy, we love him. And one thing, we expect more from him. To the Americans who have blown us up, I hope they starve and catch disease. I hope nothing helps. Poor, lonely, and cold. They are arrogant and fat. They are stupid and cruel. May they drown in a sea of blood and filth. Just die you American. Can you just die ?. It will make my heart happy. May all women be raped by beasts. Your children are forced to see ". In this first scene, girls are singing praises to their leader, Kim Jong Un and insulting the United States, the author uses propaganda techniques the use of generalities applied to particulars. In this technique, there is a habit of the population or part of the population that is stated as a habit by the population. In this case, the author sees the habit of singing songs praising the president and deriding the United States as a natural thing for the people of North Korea. A small child even sings a song that is insulting to another country (United States). Thus, the author sees an element of deliberation by the United States through this scene by creating a public opinion that the people of North Korea are used to insulting other countries, especially the United States. North Korea considers the United States of America to be their arch enemy and imparts that opinion to all North Korean society including children. This is to lead public opinion from the start that North Korea has hated the United States for a long time. This hatred was herded into public opinion to prevent any attacks that would be carried out by North Korea against the United States. Many of the threats that North Korea has posed against the United States include destroying the western part of the United States with nuclear North Korea. The author analyzes that the United States does not want the territory of the United States to be affected by a nuclear bomb. This is a counterattack by the United States against North Korea, it will stop North Korea from doing so a little bit. This is to lead public opinion from the start that North Korea has hated the United States for a long time. This hatred was herded into public opinion to prevent any attacks that would be carried out by North Korea against the United States. Many of the threats that North Korea has posed against the United States include destroying the western part of the United States with 
nuclear North Korea. The author analyzes that the United States does not want the territory of the United States to be affected by a nuclear bomb. This is a counterattack by the United States against North Korea, it will stop North Korea from doing so a little bit. This is to lead public opinion from the start that North Korea has hated the United States for a long time. This hatred was herded into public opinion to prevent any attacks that would be carried out by North Korea against the United States. Many of the threats that North Korea has posed against the United States include destroying the western part of the United States with nuclear North Korea. The author analyzes that the United States does not want the territory of the United States to be affected by a nuclear bomb. This is a counterattack by the United States against North Korea, it will stop North Korea from doing so a little bit. This hatred was herded into public opinion to prevent any attacks that would be carried out by North Korea against the United States. Many of the threats that North Korea has posed against the United States include destroying the western part of the United States with nuclear North Korea. The author analyzes that the United States does not want the territory of the United States to be affected by a nuclear bomb. This is a counterattack by the United States against North Korea, it will stop North Korea from doing so a little bit. This hatred was herded into public opinion to prevent any attacks that would be carried out by North Korea against the United States. Many of the threats that North Korea has posed against the United States include destroying the western part of the United States with nuclear North Korea. The author analyzes that the United States does not want the territory of the United States to be affected by a nuclear bomb. This is a counterattack by the United States against North Korea, it will stop North Korea from doing so a little bit. The author analyzes that the United States does not want the territory of the United States to be affected by a nuclear bomb. This is a counterattack by the United States against North Korea, it will stop North Korea from doing so a little bit. The author analyzes that the United States does not want the territory of the United States to be affected by a nuclear bomb. This is a counterattack by the United States against North Korea, it will stop North Korea from doing so a little bit.

b. At minutes 01: 49-02: 07: American media reports about Kim Jong Un and the North Korean stateproduced nuclear. These nukes will be used to destroy the western part of the United States. The current communication media most widely seen by the public are the internet and television. In this scene, the USA media reported that Kim Jong Un, the leader of North Korea, who had not proven his ability and was still very young in leading North Korea, would destroy the northwestern part of the United States of America, here the author saw an antipathy sent directly by the United States about Korea. North. The hatred expressed by the United States through the news is proven by the words they use. Media in this case is used by the United States through the film The Interview to emphasize how dangerous Kim Jong Un is and can threaten the lives of many people, especially the people of the United States. This is a persuasive technique used by the United States to invite the audience to jointly eradicate Kim Jong Un and his authoritarian attitude as a leader.

c. At minutes 02: 08-06: 18: The show Skylark Tonight shows how a rapper Eminem admits he is gay and makes Dave's show rise in ratings. In the first chapter the author has described the characteristics of liberalist state propaganda, one of which is: Paying attention to individual interests where individual rights occupy the main place, individual individuals are given the freedom to pursue happiness and pursue social status or achievements or abilities. Freedom and Human Rights are the very basics of a liberal state. This is evidenced by the existence of regulations to allow same-sex marriages. At the Skylark Tonight show, Eminem the rapper who claims to be a homosexual is surprising but not wrong for the people of the United States. Other than that, in this scene we can also see that the media of the United States is a media that is flexible and flexible. Nothing is wrong in a media world in the United States, as long as it does not violate human rights and human freedom will not be a problem. In this scene, the writer chooses the Offensive Propaganda propaganda technique, which is propaganda that is launched to attack the interests of other parties so that it can confuse the position and then impose the desired conditions. The writer chooses to choose this propaganda technique to see how the Skylark Tonight show shows how fun 
and free the life of the people of the United States is, this is very contrary to the life of North Korea, which everything is centered on the government.

d. At minutes 12: 15-13: 30: Dave tells Aaron that it turns out that North Korean president Kim Jong Un really likes their program and wants to do an interview with Dave and Aaron. In this scene, Kim Jong Un is reported to have liked several television shows in the United States, one of which is Skylark Tonight. This is a fun thing for Dave, this is due to the opportunity to keep Aaron to be the producer. In this scene, the writer saw the director's desire to emphasize this scene, which is where there is a repetition of Kim Jong Un's words several times, as if to show that Kim Jong Un is the one who is at fault here. Based on this scene, the writer chooses the Insinuation propaganda technique, which is a way of propaganda by exaggerating rumors, especially those concerning the honor of a leader. Kim Jong Un with the Communist Juche ideology that the author mentioned in the previous chapter 1 considered that external driving factors would cause the state to go out of control and society would rebel so that the country would be even more destroyed. The closed attitude that North Korea uses to the outside world is an action taken by North Korea to prevent other ideological views from entering and the whip of the Kim family's power from being destroyed, this can be proven by how all people's movements are controlled by the government.

e. At minutes 51:17 - 52:10: Kim Jong Un announces that in North Korea the food needs are prosperous and fulfilled, this can be seen from the food stores that are listed in North Korea and the weight of children in North Korea is fat. Here also Kim Jong Un shows Dave his car collection, most of Kim Jong Un's cars are American brands. In this scene, the writer saw America showing that North Korea was lying because the United States provided food aid to North Korea. In February 2012, North Korea postponed a nuclear test following a meeting with US envoys in Beijing, the United States directly announced 240,0oo tonnes of foodstuff assistance to North Korea for its willingness to postpone a nuclear test. This policy taken by the United States is a very good diplomatic action, where two problems were resolved at once, namely the resolution of the nuclear problem and the great famine that had hit North Korea since the 1990s. Food needs that are not available to 22 million people. With this action taken by the United States, it is hoped that the relationship between the United States and North Korea can improve. The reality is quite the opposite, but it is a good opportunity to be included in this film that North Korea has lied by claiming its country as a prosperous country. A lie that is actually known by the public. The United States in this case as The Doctoring of Facts, namely by changing the facts contained in society in such a way that it is not known. Can be used in advertising activities.

f. At minutes 52: 15-53: 23: It turns out that Katy Perry (Firework) is Kim Jong Un's favorite singer. In this scene, Dave finds that it turns out that Kim Jong Un likes Katy Perry Firework's song. Actually Kim Jong Un doesn't want to admit that he likes this song, it's not Dave if he can't get what he wants. Finally, with Dave's persuasion, Kim Jong Un admitted that he liked Katy Perry's song by singing it too. It was also here that Kim Jong Un began to open up to Dave about himself. Thus, the writer finally concludes to analyze this scene with the propaganda technique An Intolerant air or Tone. An Intolerant air tone is a propaganda activity conveyed by someone (usually a propagandist who is counter-propaganda) who puts forward his propaganda openly and is carried out blindly. In this film it is clearly shown how weak Kim Jong Un really is. He needed other people to direct him to find his true self. We can see that Kim Jong Un in this movie can't look Dave in the eye because he already knows the fact that he likes American music. This is a crude form of propaganda indeed, considering that everyone knows how bad North Korea's relationship with the United States is. This propaganda indeed benefits the United States of America to create public opinion without spending large sums of money to spread rumors.

g. At minutes 01:12-01:13:03: Dave finds out the truth that the food shop that Park Sook Yin showed him turned out to be a fake. The shop was just a tool to trick Aaron and Dave. The death of Kim Jong Un's two trusted generals made him stressed and promised to take their revenge on whoever killed the two generals. Kim Jong Un also insulted the United States and would destroy it with missiles. Dave was there, he was a little surprised and left the room. Dave finally saw the truth, the 
supermarket was fake and he had been lied to by Kim Jong Un. Everything that Kim Jong Un did to Dave was all lies and Dave just realized. Dave is furious and wants revenge against Kim Jong Un. Based on the scene above, The author chooses the Offensive Propaganda propaganda technique, which is propaganda launched to attack the interests of other parties so that it can confuse positions and then impose the desired conditions. In this case a lie is what it wants to show. The United States wants to show that Kim Jong Un is a liar and cannot be trusted. Everything he does is not for the benefit of the country or his nation, but only for his own sake and also for the legitimacy of the pillars of the Kim family, Kim Jong Un is a con artist. This was done by Kim Jong Un so that the image of himself and his nation would not be known to the outside world. So that this cannot disrupt the system that has been built so far. Kim Jong Un wants the outside world to know that all the facts in his country that have been exposed to the outside world are slowly being erased by the presence of Dave Skylark through his TV show. The right way to improve self-image, but the wrong way is when all the truth is revealed at the wrong time.

h. At minutes 01:16:32-01:17:24: Park Sook Yin hates Kim Jong Un because he is a bad leader. Park Sook Yin wants Kim Jong Un to be replaced. The writer feels this film is really a propaganda film. The film writer and director did not immediately show how cruel and evil Kim Jong Un's behavior was, but the audience was slowly brought in with a very smooth plot and when the audience was complacent, the director began to enter the real facts without the audience realizing that they ended up being carried away by the story. and make it a fact that actually happened. That, Kim Jong Un is a cruel person and a liar. In this scene, Park Sook Yin's communications secretary, Kim Jong Un's men did not like Kim Jong Un and thought that Kim Jong Un should be removed from his position as leader and replaced by someone else. The United States through this film wants to show that even in their own country not everyone likes Kim Jong Un and thinks his leadership is also problematic. The United States wants to show the world that many North Koreans want Kim Jong Un to step down from the powerhouse. The suffering of the people, the death penalty in front of everyone, the hunger that never ends and many North Koreans who fled to other countries because they are not strong with the North Korean state. The United States through this film wants to show that even in their own country not everyone likes Kim Jong Un and thinks his leadership is also problematic. The United States wants to show the world that many North Koreans want Kim Jong Un to step down from the powerhouse. The suffering of the people, the death penalty in front of everyone, the hunger that never ends and many North Koreans who fled to other countries because they are not strong with the North Korean state. The United States through this film wants to show that even in their own country not everyone likes Kim Jong Un and thinks his leadership is also problematic. The United States wants to show the world that many North Koreans want Kim Jong Un to step down from the powerhouse. The suffering of the people, the death penalty in front of everyone, the hunger that never ends and many North Koreans who fled to other countries because they are not strong with the North Korean state.

i. At minutes 01:30:49-01:32:45: Kim Jong Un cries in the middle of the interview. Kim Jong Un is a human being, not a half-god. Daave did an incredible trick to get a Kim Jong Un weak spot. Dave knows that Kim Jong Un is especially weak against the shadow of his father, Kim Jong Il. Kim Jong Un, who felt that he could be as great as his father, felt cornered by David's words saying that Kim Jong Un was weak and his father was greater than him. Kim Jong Un cried. In this scene, the writer has a message to convey about a new, favorable and acceptable fact, namely: that the demigod Kim Jong Un can also cry like an ordinary human. Kim Jong Un is not a demigod or god. He is just an ordinary human like a normal human, the difference is that Kim Jong Un is a president. This is also used to deny the fact that circulating in the public how great he is. Actually this is the most excellent scene for propaganda according to the author, this scene is also very suitable to be included at the end of the film. All the facts that have been given to the audience at the beginning of the film and the middle of the film are further strengthened and even continue to stick in the minds of the audience that Kim Jong Un is a weak leader without nuclear in his hands. 
j. At minutes o1: 40:25-01:41:08: Kim Jong Un died as a result of being shot by the tank used by Dave. This is the last scene by Kim Jong Un. Kim Jong Un's hatred towards Dave who betrayed him and humiliated him in front of all people around the world. Dave is not dead, he is wearing a bullet proof vest. Dave, Aaron and Park Sook Yin tried to escape from the chase of Kim Jong Un using a helicopter and the three of them with a tank. Kim Jong Un ordered his men to fire nukes at them while Dave and his friends shot Kim Jong Un's plane. The plane exploded and Kim Jong Un died. The end of the story here is also told that North Korea experienced a revolution and they can feel all access to the outside world. Based on this scene,

\subsection{Important events in the film The Interview}

The film The Interview is a film that will be released on December 25, 2014. However, when the threats and terror that came to Sony Pictures came, Sony Pictures and a number of theaters canceled the screening of The Interview film in their theaters. For information, a number of major cinema chains in the United States such as AMC Entertainment, Regal Entertainment, and Cinemark chose not to screen the film The Interview after being threatened by hackers. In fact, Sony Pictures is not planning to cancel the release of The Interview. They will still release the film as scheduled on December 25, 2014. However, Sony Pictures finally decided to cancel the release of the film. "A number of theaters came to us one by one in a very short period of time. We were very surprised, and they decided not to show the film. We also have no choice but to cancel the screening, "added Lynton. Even so, Lynton plans to release the film The Interview via video-on-demand (VOD). But unfortunately, no VOD distributor is yet interested in playing The Intreview. The Interview itself is a comedy film starring James Franco and Seth Rogen.The two are told to travel to North Korea and try to kill Kim Jong Un. North Korea criticizes the film and calls it an 'act of terrorism' 45 44. The film The Interview begins when the president of North Korea Kim Jong Un is known to like Dave Skylark's Skylark Tonight show. Dave felt proud and told his producer Aaron Rapaport to invite Kim Jong Un to Dave's show. Finally, Kim Jong Un also wants to be interviewed by Dave Skylark on the condition that all questions to be asked come from North Korea. Dave and Aaron agree. They left for North Korea to conduct an exclusive interview with Kim Jong Un and also the mission of the United States intelligence agency to assassinate Kim Jong Un.

North Korea protested to the UN council regarding the latest comedy film starring Seth Rogen and James Franco entitled The Interview They did not accept because the film tells of an attempted assassination of leader Kim Jong-Un which was packaged in a comedy form. They also asked that the release of the film be blocked. The UN Ambassador to North Korea, Ja Song Nam has sent a letter to the UN Secretary General, Ban Ki-moon. The letter stated that The Interview's storyline had insulted and killed their supreme leader. North Korea requested that the letter be circulated as an official document to members of the General Assembly and the United Nations Security Council for their consideration. Barrack Hussein Obama, the president of the United States, does not care about North Korea's report to the United Nations. Obama feels that the release of The Interview film should not be canceled on the grounds that it has restricted the freedom of American society to work. This also applies to several American artists who have commented on the film The Interview.

In the case of America and North Korea we cannot defend right and wrong, the reason is that the two countries have different ideologies and points of view in looking at the problem. America, which believes in individual rights and individual freedom, is first, while North Korea considers class equality to be the first. So, in essence America and North Korea will never have one view in any case. Now, the problem with North Korea and America is when North Korea threatens to send its nukes to the west coast of America. It is a harsh threat that America cannot take lightly, considering North Korea's nuclear power is indeed formidable. The release of the film The Interview this could be one way for the United States to prevent actions that North Korea will take against America. Further explanation will be described in the next subtitles.

3.3. Sara Mills's Critical Discourse Analysis in The Film The Interview.

Sarah Mills's critical discourse analysis pays attention to the structure of how actor positions are represented in the text. In this explanation, the position of the subject of the object and the position of 
the reader / audience. While Sara Mills 'analysis has written a great deal on women's representation, Sarah Mills' approach can be applied to other areas as well.

a. Position of Subject-object.

Sara Mills's critical discourse analysis begins with an analysis of the subject's position of the actor in the film. First, the writer determines the subject and object in the film The Interview. The subject is Dave and Aaron (United States side) and the object party is Kim Jong Un (North Korean side). Based on Sara Mills' analysis on the position of subject and object, we can see in the first discourse of the film The Interview with the discourse "Die You America". This discourse describes the longstanding hatred of the North Korean people towards the United States, this can be seen from a young child who passionately and loudly sings humiliating songs for other countries. Therefore, the writer finally presented the North Korean national anthem. In this analysis the writer sees a justification for the position of the subject towards the object, the truth presented by the subject about the object that is detrimental to the object reinforces the position of the subject that is harmed by the object. In fact, when examined further in the lyrics of the North Korean national anthem, there are no song lyrics that mention the destruction of the United States. This fact reconstruction will benefit the subject as the narrator. In the following discourse "Even though Kim Jong Un mobilized his people with screams and destruction from the United States, he was known to love US shows namely The Bigbang Theory and Skylark Tonight". In this discourse, if taken from the subject system, it illustrates that Kim Jong Un (North Korea), a country that adheres to the ideology of Communism, likes the United States program with the ideology of Liberalism. The difference in ideology between the two countries has given a negative impression. Not only that, in the film we can see that there is a bad relationship between countries with the discourse of "leaders who are not competent with their nuclear ambitions". If we examine further the ideology of Communism is not an ideology that we can say is a wrong ideology, ideology is the point of view and way of thinking of a country and no one is to blame for that. Thus, the writer takes the outline of Sara Mills' critical discourse analysis based on the subject-object position in the film The Interview is dominated by the subject. The object statement in this film only follows the storyline made by the subject and there is not even a single object statement that defends himself or his country.

b. Position of Audience/Reader.

In the film The Interview, the audience is important and influential in the success of the film. According to Sarah Mills, text or discourse is the result of a negotiation between the reader and the writer. The writer or director will consider the presence of the audience. This film tries to bring the facts that exist and are collected so that it is made in the form of a comedy film. Kim Jong Un (North Korea) is positioned as a social actor in films. Kim Jong Un is told as the leader of the North Korean state who likes US events, one of which is Skylark Tonight. American news opposed Dave and Aaron's departure to North Korea at that time, there Kim Jong Un treated them well, especially to Dave. Kim Jong Un in this film is known as a person who likes American culture, including American songs, namely: Katy Perrry with the title Fireworks. Kim Jong Un's character is also shown as a weak character, easy to cry but temperamental. He will immediately kill the person who made him angry. This is evident from Kim Jong Un's anger towards Dave when "why did you let your people starve to death?" Dave's words ignited his anger and shot Dave, then there is a discourse which states that Kim Jong Un feels pressured by the power he has. This is evident from the words of Kim Jong Un "My father said by drinking margaritas he is a weak man". Kim Jong Un is afraid of his own father. The position of the audience here is invited to become a hero in the film, the CIA's plan to assassinate Kim Jong Un with the help of Dave. said the hero to be extraordinary for Dave if he killed Kim Jong Un and without the audience knowing they confirmed it. Whereas if it is examined further, killing someone is tantamount to eliminating one's freedom of life and is against the ideology of democracy which wants individual independence. Based on the Sara Mills analysis, this is the crocodile code interpellation, namely: making a confession or fact that is believed or 
accepted together. Thus, the writer sees that the position of the audience has unconsciously created an individual acceptance of the positions made by the storytelling subject that has been deliberately carried out and accepts them as a form of reality or truth.

\section{CONCLUSION}

In the first phase, we have started writing with important events that occurred outside the film The interview where there was a refusal from the North Korean side of the screening of this film. Withdrawal of the film The Interview from cinemas, the loss suffered by the Sony Pictures label and the existence of hackers who entered the Sony Pictures site allegedly from North Korea based on the IP address. The President of the United States, Barack Obama also expressed his opinion on the film The Interview and also the opinion of several Hollywood artists. In this level of analysis, we can see that even before the film was aired, the synopsis of the story had made the leaders of the countries concerned who were the main characters in this film angry and declared their resistance. Political action was taken up to the United Nations (UN). In this film, we find Kim Jong Un liking the Skylark Tonight program, which is an event produced by the United States. This is a matter of debate considering the relationship between North Korea and the United States has not been good since the Korean war in 1955, this continued until Dave conducted an interview with Kim Jong Un. Kim Jong Un's cleverness in tricking Dave into believing him and Aaron and Dave's assassination attempt becomes a problem in this film. At the level of discourse in the view of Sara Mills' critical discourse analysis, in two stages of analysis, namely the position of the subject of the object and the position of the reader or audience, we find that, at the level of the position of the subject of the object, Dave Skylark and Aaron Rapaport who are represented as the United States are the subjects or storytellers while Kim Jong Un who are represented as the North Korean side are the objects. In The Interview film, it re-presents like a summary of Kim Jong Un's facts that we know so far or have circulated in the community. Starting from the cruel and ambitious Kim Jong Un, what has never happened is that Kim Jong Un was interviewed by the United States Media and the last one was the death of the Supreme Leader himself which was shown at the end of the film. However, in this film there is no defense or protection against the facts described in the film. We can see this from all aspects of the film in terms of characterization, characterization, plots and settings. The position of the subject object explains that the United States explains its desire and will in portraying a Kim Jong Un which can lead to inequality because there is no explanation in the film for this fact. In the position of the audience, we can also see that, like Sara Mills, the audience will identify itself against the position of truth which is arranged hierarchically. In the film The Interview, we can see the depiction of Kim Jong Un's character and behavior in this film and also how dangerous Kim Jong Un is to the world. Kim Jong Un's death is a must. This plot has led to the United States being the right side (Protagonist) and North Korea as the antagonist. Thus, the audience will identify themselves to the party who is in the right position. At the level of propaganda, this film has a tendency to describe the nature of Kim Jong Un which is depicted clearly based on the perception of the subject. Nothing in the scene shows the kindness of a Kim Jong Un or why he became that cruel. The author sees the propaganda very clearly in the figures of Kim Jong Un himself and Park Sook Yin. Two North Koreans who have important roles in this film. In this film, these two characters show the true face of North Korea and the things that happened in North Korea. However, the author sees no historical evidence conveyed in the film regarding Kim Jong Un's depiction here. According to the author, The Interview film is an appropriate propaganda film when looking at the relations between North Korea and the United States, which are currently tense, This is because the presence and form of this film which is present as a medium of entertainment makes the audience or the public do not know the meaning or other purpose behind the film that the audience is watching. Unconsciously the audience may agree with certain ideas or questions according to what the audience sees in the film, and he thinks of it as the truth which is just the way it is. This position is what makes propaganda through film very widely used by any party. The writer sees the thought construction made in this film very neat and really makes the audience believe it and marks it as fact. The thought that was formed started from the ruse of Kim Jong Un and the real truth was not what it seemed. Free America and authoritarian North Korea. The fact that Kim 
Jong Un likes American programs makes his image negative and the audience here is a little confused by Kim Jong Un's kindness to Dave and this is used by the writer to provide new facts for the audience with the right and reliable timing. The author considers this film to be a propaganda film that has an influence on people who want to have more information about North Korea.

\section{REFERENCES}

Baran, S. J., Davis, D. K., \& Striby, K. (2012). Mass communication theory: Foundations, ferment, and future.

Chowdhury, M. F. (2015). Coding, sorting and sifting of qualitative data analysis: Debates and discussion. Quality E Quantity, 49(3), 1135-1143.

Csikszentmihalyi, M. (2015). The systems model of creativity: The collected works of Mihaly Csikszentmihalyi. Springer.

Fahmi, A. S. (n.d.). Dominasi Ideologi Islam di Media (Studi Kritis Berita Isu Suap Sertifikasi Mui di Tabloid Suara Islam).

Ferawati, A. (2012). Kebijakan Kim Jong Il Terhadap Pengembangan Nuklir Di Korea Utara Tahun 1998-2008.

Indarto, Y. W. (2012). Budaya Pandalungan Dalam Budaya Organisasi Pemerintahan (Studi Kasus di Kantor Kecamatan Suboh-Situbondo). University of Muhammadiyah Malang.

Inkeles, A. (2013). Public Opinion in Soviet Russia. Harvard University Press.

Jati, K. P. (n.d.). Implementasi Kerja Lembaga Sensor Film Terhadap Film-Film Islam. Fakultas Ilmu Dakwah dan Ilmu Komunikasi Universitas Islam Negeri Syarif ....

Jervis, M. G., \& Drake, M. (2014). The use of qualitative research methods in quantitative science: A review. Journal of Sensory Studies, 29(4), 234-247.

Kellner, D. (2011). Cultural studies, multiculturalism, and media culture. Gender, Race, and Class in Media: A Critical Reader, 3, 7-18.

Khan, S. N. (2014). Qualitative research method: Grounded theory. International Journal of Business and Management, 9(11), 224-233.

Lutz, T. (2015). Cult of Personality: North Korea under Kim Il-Sung.

Nadjib, E. A. (2015). Sedang Tuhan pun Cemburu. Bentang Pustaka.

Oktora, D. F. (2015). Analisis Isi Film Soul Surfer Studi Analisis Isi Tentang Film Soul Surfer Ditinjau Dari Teori Motivasi Tiga Kebutuhan David Mcclelland.

Park, Y. S. (2014). Policies and ideologies of the Kim Jong-un regime in North Korea: Theoretical implications. Asian Studies Review, 38(1), 1-14.

Prabowo, A., \& Heriyanto, H. (2013). Analisis pemanfaatan buku elektronik (e-book) oleh pemustaka di perpustakaan SMA Negeri 1 Semarang. Jurnal Ilmu Perpustakaan, 2(2), 152-161.

Radner, H., \& Stringer, R. (2012). Feminism at the movies: Understanding gender in contemporary popular cinema. Routledge.

Rifwan, A. M. I., Purnama, H., \& Si, M. (2015). Analisis Naratif Film Captain America: The First Avenger (Analisis Naratif Dengan Teori Vladimir Propp). Program Studi Ilmu Komunikasi, Telkom University.

Risdiansyah, D. (2011). Tema Persahabatan dalam Film (Analisis Isi terhadap Film" Kite Runner). University of Muhammadiyah Malang.

Sabatier, V., Craig-Kennard, A., \& Mangematin, V. (2012). When technological discontinuities and disruptive business models challenge dominant industry logics: Insights from the drugs industry. Technological Forecasting and Social Change, 79(5), 949-962.

Sanborn, F. W., \& Harris, R. J. (2013). A cognitive psychology of mass communication. Routledge.

Sartika, E. (2014). Analisis isi kualitatif pesan moral dalam film berjudul "Kita versus Korupsi." Jurnal Ilmu Komunikasi, 2(2), 63-77.

Shi-Xu. (2012). Why do cultural discourse studies? Towards a culturally conscious and critical approach to human discourses. Critical Arts, 26(4), 484-503.

Siyoto, S., \& Sodik, M. A. (2015). Dasar metodologi penelitian. Literasi Media Publishing.

Slavich, G. M., \& Zimbardo, P. G. (2012). Transformational teaching: Theoretical underpinnings, basic principles, and core methods. Educational Psychology Review, 24(4), 569-6o8.

Syafrul, R. C. (2014). Analisis Semiotika Terhadap Makna Jihad Dalam Film Zero Dark Thirty.

Turow, J. (2011). Media today: An introduction to mass communication. Taylor \& Francis.

Wardani, W. (2011). Wacana Nasionalisme Dalam Film (Studi Dengan Analisis Wacana Model Van Djik Terhadap Film Pagar kawat Berduri (1961), Bandung Lautan Api (1974) dan Merah Putih (2009)).

Watt, D. P. (2012). The Urgency of Visual Media Literacy in Our Post-9/11 World: Reading Images of Muslim Women 
in the Print News Media. Journal of Media Literacy Education, 4(1), 32-43.

Welch, C., Piekkari, R., Plakoyiannaki, E., \& Paavilainen-Mäntymäki, E. (2011). Theorising from case studies: Towards a pluralist future for international business research. Journal of International Business Studies, 42(5), $740-762$.

Yilmaz, K. (2013). Comparison of quantitative and qualitative research traditions: Epistemological, theoretical, and methodological differences. European Journal of Education, 48(2), 311-325.

Yongchun, L. (2015). North Korea's Guiding Ideology and Its Impact. In China and North Korea (pp. 225-240). Springer. 